\title{
Determinants of Export Performance in Ethiopia (Time Series Analysis)
}

\author{
Deresse Dalango \\ Department of Economics, Wolaita Sodo University, Ethiopia
}

\begin{abstract}
Although, export plays a vital role in an economy, there have been wide variations in countries export performance. The objective of this study was examining the determinants of export performance in Ethiopia using time series data running from 1981 to 2018 through employing Autoregressive Distributed Lag (ARDL) model. The stationarity properties of the data was detected using Augmented Dickey-Fuller (ADF) and the result indicates all the variables are stationary at level and first difference evidencing the effectiveness of ARDL model. The ARDL bound test used to test the existence of long-run link among the variables and the result confirmed that there is long run relationship between export and independent variables. The diagnostic test results also show that the model does not suffer from non-normality, heteroscedasticity, serial correlation and instability of parameters. The long-run coefficient result for our model evident that foreign direct investment and per capita GDP are positively associated with exports in Ethiopia while rate of inflation has negative and significant effect. In the short run dynamics, ECM model results reveals that FDI, per capita GDP and capital formation are significant and positively affect the export performance of Ethiopia in the short run. However, the rate of inflation still negatively and significantly affect the export in the short run. The Policies measures that geared towards improvement in real per capita GDP, attractive to FDI and economic stability would improve export performance.
\end{abstract}

Keywords- Export, Co-integration, ARDL, Ethiopia

DOI: $10.7176 / \mathrm{EJBM} / 12-28-02$

Publication date:October $31^{\text {st }} 2020$

\section{INTRODUCTION}

The increased development of globalization have outshined the international commercial equation and undermined the effectiveness of the traditional tools (Seyed M. Elahi., 2014). The poor countries are widely advised to accept outward looking strategies in their transition toward progress. The classic exemplary are the East Asian tigers, they transformed their economy through out looking strategy. The emerging countries like Chile, Tunisia, Botswana and Mauritius have also witnessed tremendous and sustainable exports (World Bank, 2012). Furthermore, fast-growing countries such as Brazil and China have buoyed on world markets (World Bank, 2012). The wide market share and competition advantage obtained from international market through exportation plays a vital role on the growth and survival of companies (Navarro et al., 2009, Rabino, 2004). Exportation allows firms in poor countries to enlarge their markets and enable to benefit from economies of scale. Moreover, through exports a country get opportunity to receive foreign exchange earnings, increase productivity and increase employment which in turn encourage economic growth.

The countries that have strong participation in international market through sound export performance gradually improve their economic performances. Although, export plays a vital role in an economy, there have been wide variations in countries export performance over the past two decades. For instance the East Asian countries have shown real exports increase by more than $800 \%$ since the early 1970 s, whereas those of SubSaharan Africa have increased by only $70 \%$. This divergent performance has questioned that some countries are benefiting from globalization others are left behind (Redding and Venables, 2002). This is may be due to a number of factors with different level of magnitude that influence the export performances of the countries depending on the characteristics of the economies.

Several studies have been conducted regarding the different factor that influence the performance of export. According to Kumar (1998) and Fugazza (2004), the size of GDP has positive and significant impact on export expansion. The result show that large size of GDP creates environments for investment decisions and then lead to expanded export. On the other hand, Majeed \& Ahma (2006) argue that, even though both GDP and growth in GDP have a positive impact on export expansion, GDP growth is an indicator of future potential and sustainability of production level. The study by Mohamad et al. (2009) point out that appreciation of real exchange rate has a strong negative impact on export performance. The other studies found positive and significant effect of real exchange rate on export performance, basing their argument on that real undervaluation or depreciation increases the profitability of the tradable sector, and leads to an expansion of the share of tradables in domestic value added (Rodrik, 2009). However, real appreciation or overvaluation hampers exports and leads to a fall in economic growth (Easterly 2005; Johnson, Ostry, \& Subramanian 2007). The above confrontational results show that there were no cross-cutting empirical findings that concludes the responsible factor for variation in export performance among countries. Hence, it is imperative to look over the determinants of export performance in low income 
country, particular in Ethiopia. The aim of this study is to investigate the determinants of export performance in Ethiopia over the period of 1981 to 2018 years through applying autoregressive distributed lag econometric model (ARDL)

\section{LITERATURE REVIEW}

In recent globalized economy, exporting has been one of the fastest growing economic activities in both developed and developing nations. The over growing liberalization, integration and competition in the world economies considered as pushing factors for the increasing engagement of firms in exporting activities. According to Czinkota and Ronkainen (1998), exportation is a vital business activity for nations' economic health, since it significantly contributes to employment, trade balance, economic growth, and higher standard of living. Export leads to sustainable competitive advantage of firms in the raging market, due to improvement of financial position, increased capacity utilization, higher technological standards, and attainment of a desired performance (Leonidou and Katsikeas, 1996). Exporting can be an engine for the individual firm's growth and profitability, and for the nation's economic growth (Hatemi and Irandoust, 2001). Once a firm enters the international market through exporting, the outcome is improved by economies of scale which reduce the cost of goods produced both for the domestic and international markets (Albaum, Strandskov, Duerr, and Dowd, 1989). Thus, export has significant influence on individual firm expansion as well as national economic activity.

Following Nigeria, Ethiopia is the second most populated country in Africa with an estimated population of more than 100 million people. The agricultural sector considered as the base of economy, accounted for about 42 percent of the gross domestic product (GDP), about 80 percent of total employment, and nearly 80 percent of foreign currency earnings of the country (MoFED, 2009). Ethiopia's major exports include coffee, oil seeds, 16 gold, chat, flowers, pulses, and live animals. Coffee is the leading export, constituting $30.6 \%$ of total exports by value in the year 2009 (MOFED, 2009). While, its share in total world exports is still very low, amounting only $0.01 \%$ in 2006 (WTO, 2007). The Ethiopia's external trade faces both supply side and demand side problems. On the supply side it dependents' on few primary products, characterized by large fluctuations in volume and a very high degree of concentration of exports on few commodities and on the demand side a low income elasticity for the type of commodities that Ethiopia exports, declining prices for its exports, and limited destinations for Ethiopian exports (Alemayehu, 1999 and Abay and Zewdu, 1999). Like any other African countries, Ethiopia's exports face market access problems in the international markets (UNIDO, 2002; UNCTAD, 2008).

Different empirical studies have been conducted using different methods regarding the factors determining export performance of different countries. Their result reveals that there is a big contradiction on the determinants of export growth for developing countries. Through improving long-term capital with new technologies, managerial and marketing skills, foreign direct investment inflow can perform positive contribution to economic growth and which in turn promote the export performance of the economy (Romer P. M., 1986; Grossman M. and Helpman E., 1991). However, Herve at el. (2014), found adverse effect of FDI Zanzibar's export performance. Furthermore, Majeed and Ahmand (2006) found a positive but insignificant impact of FDI on exports of developing countries. Thus, the impact of FDI on export performance becomes controversial. Its' impact depends on the motivation of FDI flow such that whether to capture the domestic market or to tap the export market. On the other hand capital formation, which is referred to as enlargement of capital stock can enhance import substitutes and economic growth by expanding export performance (Adhikary B.K., 2011; Chow G. C., 1993; Rajni P., 2013 and Solow R. M, 1962)

According to Agasha (2006), GDP, Real Exchange Rate and terms of trade have positive and significant influence on export growth rate while Foreign Price level were found to affect export growth rate negatively and significantly in Uganda. The investigation by Mulualem (2006), on Ethiopian manufacturing sector exports found positive influence of investment to GDP ratio, total factor productivity and foreign income while real effective exchange rate was found to have insignificant influence on exports. For Yishak (2009) the good institutional quality and internal transport infrastructure appear to be major determinants, whereas the real exchange rate and FDI have no statistically significant effect on Ethiopia's export performance. According to Sisay (2010), the merchandise export volumes of Ethiopia are significantly influenced by gross capital formation and trade liberalization) while other variables; like terms of trade, real effective exchange rate, foreign income, and foreign direct investment were found to be insignificant. From aforementioned indication it can be said that the influencing factor of export performance differs from country to country based on their economic and commercial policy status.

\section{Data and Methodology}

The secondary time series annual data on variables, running from 1981 to 2018, were obtained from World Bank World development indicator and international monetary fund (IMF) world economic outlook database. At first step, Unit root analysis was performed in order to test stationary properties of the variables because variables with non-stationary properties may produce spurious result if regression analysis is employed to test long run elasticity's (Gujarati, 2004). Thus, unit root tests for stationary are examined on the levels and first differences for all variables 
using the most common unit root tests, which is the Augmented Dickey-Fuller (ADF) (Green, 2003). Different diagnostic test like Serial correlation test (Brush \& Godfray LM test); Heteroscedasticity test (Brush-Pagan \& Godfray LM test); Normality (Jaque-Bera test) and the parameter stability test of the model was also conducted. The co-integration test has been undertaken on the F-statistic with help of the bound test of ARDL.

Autoregressive Distributed Lag (ARDL) model is the more statistically significant approach to determine the co-integration relation between variables in small samples than Johansen co-integration techniques, which require large data samples for valid estimation of the parameters (Pesaran et al., 2001 and Nayaran, 2004). Furthermore, ARDL model with the appropriate number of lags will address autocorrelation and endogeneity problems, because it is possible that different variables have different optimal numbers of lags (Pesaran and Shin, 1999). Most importantly, the ARDL estimation can be applied whether the regressors are purely ordered zero [I $(0)]$, purely order one $[\mathrm{I}(1)]$, or a mixture of both. While other cointegration techniques require all of the regressors to be integrated of the same order. As result, we employed ARDL approach to analyses the link between Ethiopia's export and its determinants.

Therefore, ARDL model can be specified as:

$$
\begin{aligned}
\triangle \ln \left(\mathrm{EXPOR}_{t}\right)= & B_{o}+B_{1} \ln \left(\mathrm{EXPOR}_{t-1}\right)+B_{2} \ln \left(\mathrm{GDPC}_{t-1}\right)+B_{3} \ln \left(\mathrm{BCR}_{t-1}\right)+B_{4} \ln \left(\mathrm{FDI}_{t-1}\right) \\
& +B_{5} \ln \left(\mathrm{GCF}_{t-1}\right)+B_{6} \ln \left(\mathrm{INFR}_{t-1}\right)+B_{7} \ln \left(\mathrm{EXR}_{t-1}\right)+\sum_{i=1}^{s} \alpha_{i} \Delta \ln \left(\mathrm{EXPOR}_{t-i}\right) \\
& +\sum_{j=1}^{r} \alpha_{j} \Delta \ln \left(\mathrm{GDPC}_{t-j}\right)+\sum_{k=1}^{s} \alpha_{k} \Delta \ln \left(\mathrm{BCR}_{t-k}\right)+\sum_{l=1}^{x} \alpha_{l} \Delta \ln \left(\mathrm{FDI}_{t-l}\right) \\
& +\sum_{m=1}^{y} \alpha_{m} \Delta \ln \left(\mathrm{GCF}_{t-m}\right)+\sum_{n=1}^{x} \alpha_{n} \Delta \ln \left(\mathrm{INFR}_{t-n}\right)+\sum_{p=1}^{w} \alpha_{p} \Delta \ln \left(\mathrm{EXR}_{t-p}\right)+v_{t}
\end{aligned}
$$

Where: - EXPOR - Total exports volume in US dollar

- FDI - Foreign direct investments in US dollar;

- $\mathrm{GCF}$ - gross capital formation as proxy for domestic investment.

- $\quad$ GDPC - per capita GDP;

- $\quad$ BCR - domestic bank credit;

- $\quad$ INFR - Inflation rate;

- $\quad$ EXR - Official Exchange Rate.

The symbol $\Delta$ is the first difference operator, $\mathrm{q}, \mathrm{r}, \mathrm{s}, \mathrm{v}, \mathrm{y}, \mathrm{x}$, and $\mathrm{w}$ are the lag length with their respective variables and $\mathrm{v}_{\mathrm{t}}$ error term which is assumed to be serially uncorrelated; $\beta_{1}, \beta_{2}, \beta_{3}, \beta_{4}, \beta_{5}, \beta_{6}$ and $\beta_{7}$ are the coefficients that measure long-run elasticities between the variable. Whereas $\alpha_{\mathrm{i}}, \alpha_{\mathrm{j}}, \alpha_{\mathrm{k}}, \alpha_{\mathrm{l}}, \alpha_{\mathrm{m}}, \alpha_{\mathrm{n}}$, and $\alpha_{\mathrm{p}}$ indicates coefficients that measure short-run elasticities among the variables. Based on economic theory and prior empirical results, the expected signs of the coefficients are $\beta_{2}>0, \beta_{3}>0, \beta_{4}>0, \beta_{5}>0, \beta_{6}<0, \beta_{7}(\mp)$.

From co-integrated series, the short-run elasticities can also be derived through constructing the error correction model $(\mathrm{ECM})$ in the following form:

$$
\begin{aligned}
\triangle \ln \left(\mathrm{EXPOR}_{t}\right)= & B_{o}+\sum_{i=1}^{q} \alpha_{i} \Delta \ln \left(\mathrm{EXPOR}_{t-i}\right)+\sum_{j=1}^{r} \alpha_{j} \Delta \ln \left(\mathrm{GDPC}_{t-j}\right)+\sum_{k=1}^{s} \alpha_{k} \Delta \ln \left(\mathrm{BCR}_{t-k}\right) \\
& +\sum_{l=1}^{v} \alpha_{l} \Delta \ln \left(\mathrm{FDI}_{t-l}\right)+\sum_{m=1}^{y} \alpha_{m} \Delta \ln \left(\mathrm{GCF}_{t-m}\right)+\sum_{n=1}^{w} \alpha_{n} \Delta \ln \left(\mathrm{INFR}_{t-n}\right) \\
& +\sum_{p=1}^{w} \alpha_{p} \Delta \ln \left(\mathrm{EXR}_{t-p}\right)+\rho E C M_{t-1}+\varphi_{t}
\end{aligned}
$$

Where, the variable $\mathrm{ECM}_{\mathrm{t}-1}$ is the error correction term which captures the long-run relationship whereas $\alpha^{\prime} s$ are the coefficients associated with short-run dynamics of the model converging to equilibrium.

\section{Estimation Results and Discussion}

\subsection{Tests for Stationarity of Series}

The Augmented Dickey-Fuller (ADF) method was conducted to check for a unit root for all variables in both levels and first differences. Accordingly among the variables export; rate of inflation and FDI are stationary at level whereas all the remaining variables are stationary at first difference. The test result evident that none of the variables was I(2) or above and hence we moved on with the ARDL co-integration technique since it is capable of dealing with whether all variables are $\mathrm{I}(0)$ or all are $\mathrm{I}(1)$ or a mixture of both(Pesaran et al., 2001). The ADF Unit root test results are reported in Table-1 below. 
Table 1. Augmented Dickey-Fuller (ADF) unit root tests

\begin{tabular}{llcl}
\hline \multicolumn{2}{l}{ ADF-test results for series with intercept and linear trend } & \\
\hline & At level & $1^{\text {st }}$ difference & Order of integration \\
Variables & & & $\mathrm{I}(0)$ \\
LNEXPOR & $-19.07681^{* * *}$ & - & $\mathrm{I}(0)$ \\
LNFDI & $-4.418108^{* * *}$ & $-6.489022^{* * *}$ & $\mathrm{I}(1)$ \\
LNGCF & -1.532631 & $-6.172971^{* * *}$ & $\mathrm{I}(1)$ \\
LNGDPC & -0.800947 & - & $\mathrm{I}(0)$ \\
LNBCR & $-3.74207^{* *}$ & - & $\mathrm{I}(0)$ \\
INFR & $4.435708^{* * *}$ & $-3.210766^{*}$ & $\mathrm{I}(1)$ \\
EXR & 0.522260 & & \\
\hline
\end{tabular}

Source: Author's Computation Using Eviews 9.0 Package

Where significant at $1 \%(* * *), 5 \%(* *)$ and $10 \%(*)$ respectively.

\subsection{ARDL Bound Test for Co-integration}

Pesaran and Shin (1999) and Nayaran (2004), recommended choosing a maximum of 2 lags for annual data series. Accordingly, this analysis set the maximum lag length at 2 years for which are sufficiently long enough for annual data series to investigate the variable relationship and then AIC is applied to choose at the best ARDL model (Lutkephl, 2005). The F-statistics against the critical values was taken as criterion for the co-integration bounds test. The results indicates that the test is highly significant at 1\% level (table-2). As the F-statistic (28.6089) was above all the upper bound value at $10 \%, 5 \%, 2.5 \%$ and $1 \%$, the null hypothesis of no long run co-integration would be rejected. Hence, the results confirm the presence of a long-run relationship between the Ethiopia's export and its determinants comprised in this study.

Table 2: Bound Test for Co-integration

\begin{tabular}{lrc}
\hline Significance level & Lower bound & Upper bound \\
\hline $10 \%$ & 2.12 & 3.23 \\
$5 \%$ & 2.45 & 3.61 \\
$2.5 \%$ & 2.75 & 3.99 \\
$1 \%$ & 3.15 & 4.43 \\
\hline
\end{tabular}

Source: Author's Computation Using Eviews 9.0 Package

\subsection{Diagnostic and Stability Test}

The diagnostic tests show that the model does not suffer from non-normality. The histogram and Jarque-Bera normality test (Figure 1) suggest that the residuals of the model are normally distributed. In addition the diagnostic tests, the Breusch-Godfrey serial correlation LM tests reveals that the residual terms in the model are serially independent. Furthermore,

Breusch-Pagan-Godfrey test result suggests that there exists no heteroscedasticity in the residual terms of the model (Table 3).

Table-3 Result of the diagnostic test for ARDL $(2,2,2,0,0,2,0)$ model

\begin{tabular}{llll}
\hline Diagnostic Tests & Statistics & Results & Conclusion \\
\hline Heteroskedasticity Test: & F-statistic & 0.801635 & No heteroskedasticity \\
Breusch-Pagan-Godfrey & Prob. F(14,21) & 0.6591 & problem \\
& Prob. Chi-Square(14) & 0.9861 & \\
\hline Breusch-Godfrey Serial & F-statistic & 2.270080 & No serial correlation \\
Correlation LM Test & Prob. & 0.097 & \\
\hline
\end{tabular}

Source: Author's Computation Using Eviews 9.0 Package

The Normality test indicates that residuals are normally distributed as we unable to reject the null hypothesis of normality tests using Jacque-Bera at 5 percent. 
Figure 1. Normality Test of the Residuals: Histogram Notes:

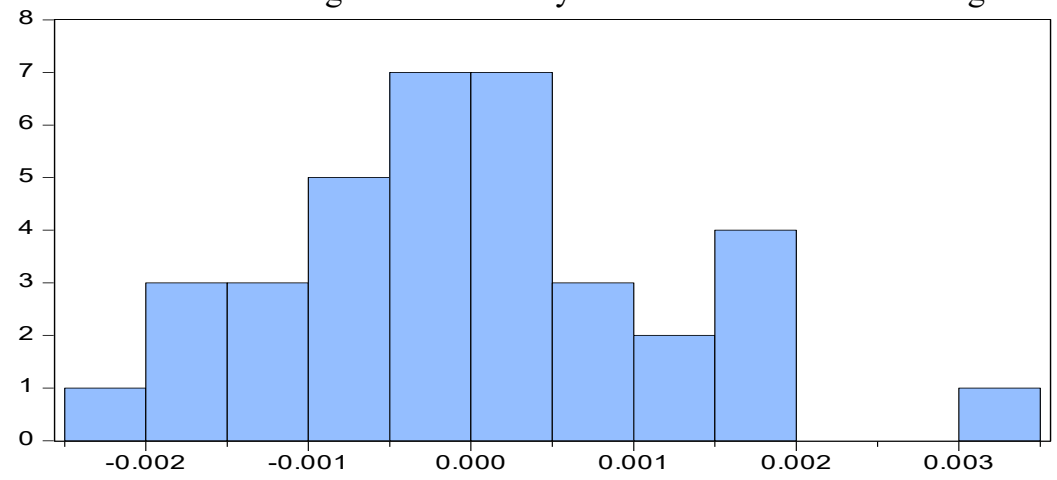

\begin{tabular}{lr|} 
Series: Residuals \\
Sample 1983 2018 \\
Observations 36 \\
Mean & $-7.41 \mathrm{e}-17$ \\
Median & -0.000109 \\
Maximum & 0.003377 \\
Minimum & -0.002441 \\
Std. Dev. & 0.001216 \\
Skewness & 0.536199 \\
Kurtosis & 3.332422 \\
& \\
Jarque-Bera & 1.890815 \\
Probability & 0.388521 \\
\hline
\end{tabular}

It is in most necessary to test the stability of the long-run parameters in conjunction with the short-run dynamic model (Pesaran and Pesaran, 2009). Accordingly, the parametric stability can be tested using cumulative of the recursive residuals (CUSUM) as well as the cumulative sum of squares of recursive residual (CUSUMQ) (Figures 2 and Figure 3). As procedure if the cumulative sum goes inside the area (can returns back) between the two critical lines, then there is parameter stability in the short- and long-run. The plots of CUSUM and CUSUMQ test statistics rests neatly within the boundaries at $5 \%$ significant level. Hence, we can conclude that long-run estimates are stable and there is no any structural break.

Figure 2: CUSUM

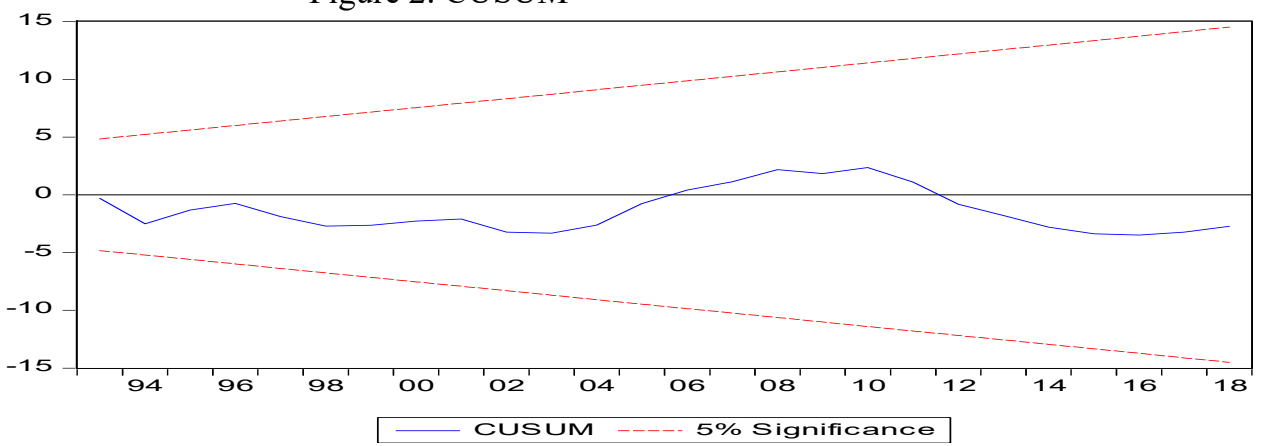

Figure 2; CUSUM SQUARE

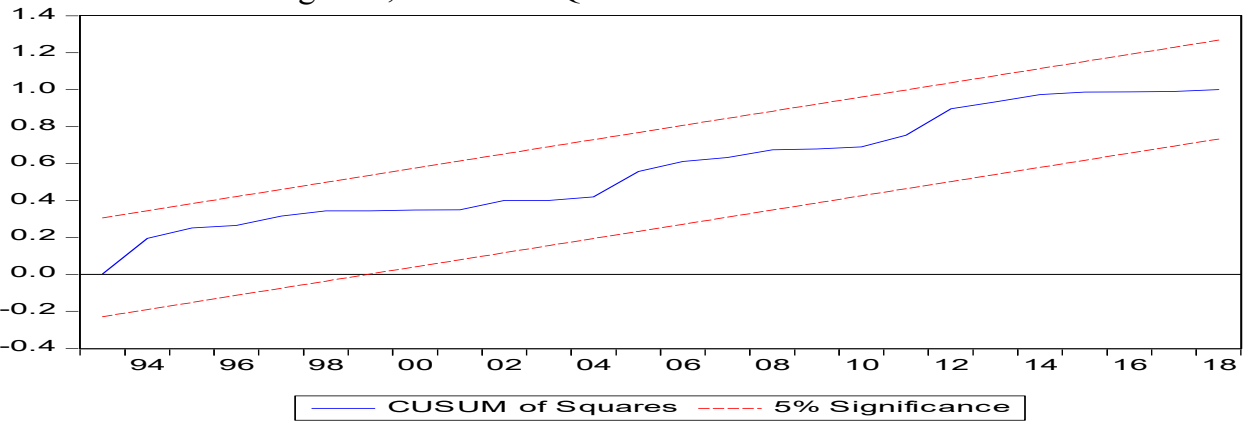

\subsection{Long-run (ARDL) and Short-run (ECM) Estimation Results}

Having the long-run co-integration relationship among the dependent and independent variables, the remaining steps might be running the appropriate ARDL model to find out the long run coefficients, which is reported in table-4 below. The long-run coefficient result for our model evident that foreign direct investment and per capita GDP are positively associated with exports in Ethiopia while rate of inflation has negative and significant effect. On the other side the remaining variables become statistically insignificant with expected sign.

The coefficient for foreign direct investment indicates a $1 \%$ increase in FDI inflow would results $8.3 \%$ increase in export volume. It is indication that the foreign investor produce exportable quality outputs and in that they improve the countries term of trade. The finding is in line with studies by Thangamani (2016), who found positive influence of FDI on Sri Lank export. The coefficient of per capita GDP shown the expected positive sign and statistically significant. This supports the argument that, increase in per capita GDP is an indicator of future potential and sustainability of production level. The finding was supported by Kumar (1998), Fugazza (2004) and Manamba (2016), they reported the positive determination of export performance on size of GDP. In the long run, rate of inflation adversely affect the export performance through destabilizing the economy. Since it is overall rise of price in domestic market, the exporting firm forced to purchase expensive input leading to high production cost. 
Table 4 Long- and short-run relationship estimation results ARDL (2, 2, 2, 0, 0, 2, 0)

\begin{tabular}{ll|ll}
\hline Variables & Long run Coefficient & Variables & Short-run results \\
\hline LNFDI & $0.083865^{* * *}$ & D(LNEXPOR(-1)) & $0.343155^{* * *}$ \\
& $(8.897107)$ & & $(35.985774)$ \\
LNGCF & -0.020296 & D(LNFDI) & $0.001738^{* * *}$ \\
& $(-0.579641)$ & & $(4.471307)$ \\
LNGDPC & $0.217782^{* *}$ & D(LNGCF) & $0.008077 * *$ \\
& $(2.550331)$ & & $(3.090577)$ \\
LNBCR & -0.021591 & D(LNGDPC) & $0.015634 * *$ \\
INFR & $(-1.067309)$ & D(LNBCR) & -0.001550 \\
& $0.006758^{* * *}$ & & $(-1.068525)$ \\
EXR & $(7.496489)$ & D(INFR(-1)) & $-0.000184 * * *$ \\
& 0.001429 & & $(-4.670020)$ \\
C & $(0.459049)$ & D(EXR) & 0.000103 \\
& $2.168507 * *$ & CointEq(-1) & $(0.459718)$ \\
& $(0.671892)$ & & $(-0.071787 * * *$ \\
& & & \\
\hline
\end{tabular}

Source: Author's Computation Using Eviews 9.0 Package

Note: the t-statistic are in parentheses and were significant at $1 \%(* * *), 5 \%(* *)$ and $10 \%(*)$

The estimation results discloses that the coefficient of the error- correction term, ECTt-1, for the export equation shown expected negative sign and is statistically significant at $1 \%$ level. The negativity implies that, it will rightly act to correct past deviations from the long run equilibrium or any shock that occurs in the short-run will be corrected in the long run. Furthermore, coefficients of the short run model show that FDI, per capita GDP and capital formation are significant and positively affect the export performance of Ethiopia in the short run. However, the rate of inflation still negatively and significantly affect the export in the short run

\section{Conclusion}

The factor determining the performance of exports varies across countries, regions and commodities. The objective of this study was examining the determinants of export performance in Ethiopia using time series data running from 1981 to 2018. The data were obtained from World Bank World development indicator and international monetary fund (IMF) world economic outlook database and analyzed by applying Autoregressive Distributed Lag (ARDL) model. The stationary properties of data were tested by ADF methods and the results show it is stationary at level and in the first difference. The ARDL bound test of Co-integration analysis was employed in order to investigate the long run relationship among the variables. The parametric stability test and other residual diagnostic test result have not shown the statistical and instability problems of our data.

The long-run coefficient result for our model evident that foreign direct investment and per capita GDP are positively associated with exports in Ethiopia while rate of inflation has negative and significant effect. In the short run dynamics, ECM model results reveals that FDI, per capita GDP and capital formation are significant and positively affect the export performance of Ethiopia in the short run. However, the rate of inflation still negatively and significantly affect the export in the short run. The Policies measures that geared towards improvement in real per capita GDP, attractive to FDI and economic stability would improve export performance.

\section{Bibliography}

Abay Asfaw and Zewdu Belete. (1999). Export Earnings Instability and Export Structure: the Case of Ethiopia. Adhikary B.K. (2011). FDI, Trade Openness, Capital Formation, and Economic Growth in Bangladesh: A Linkage Analysis. International Journal of Business and Management, 6(1), 16-28. .

Agasha Nimrod. (2006). Determinanats of Export Growth Rate in Uganda 1987- 2006.

Chow G. C. (1993). Capital Formation and Economic Growth in China. The Quarterly Journal of Economics, 108(3), 809-842.

Fugazza M. (2004). Export Performance and Its Determinants: Supply and Demand Constraints, Policy Issues In International Trade and Commodities Study Series Vol.1,No.26, Geneva, Swaziland.

Greene, W.H. (2003). Econometric Analysis, Fifth Edition, Prentice Hall, N.J. .

Grossman M. and Helpman E. . (1991). Quality Ladders in the Theory of Growth. The Review of Economic Studies, 58 (1), 43-61.

Gujarati, D. N. . (2004). Basic econometrics. New York: McGraw-Hill/lrwin. . .

Hervel D. B. G., Amoro G., Mahfoudh R. S. and Constant N. Z. S. . (2014). The Determinants of Export Performance: The Case Study of Zanzibar Export. International Journal of Economics and Finance, 6(6), 95-102. 
IMF. (2019). World Economic Outlook (WEO) database; October 2019. . .

Johnson, S.H., Ostry, J., \& Subramanian, A. (2007). The prospects for sustained growth in Africa: benchmarking the constraints. IMF Working Paper No. 07/52. [Retrieved from]. Joshi, V., \& Little, I.M.D. (1996). India's economic reforms 1991-2001, Oxford.

Kumar N. (1998). Multinational enterprises, regional economic integration and export-platform production in the host countries: an empirical analysis for the US and Japanese corporations. eltwirtschaftliches Archiv, 134, 450-483. doi. 10.1007/BF0270792.

Leonidou, L.C. and Katsikeas, C.S. . (1996). The export development process: an integrative review of empirical models, Journal of International Business Studies, Vol. 27, Third Quarter,

Majeed M. T. and Ahmad E. (2006). Determinants of Exports in Developing Countries. The Pakistan Development Review, 45, 4 Part II, 1265-1276.

Manamba Epaphra . (2016). determinants of Export Performance in Tanzania.

Menji, Sisay . (2010). Export Performance and Determinantsin Ethiopia, Munich Personal RePEc Archiv.

Mohamad, S., Nair, M., \& Jusoff, K. (2009). Exchange rates and export competitiveness in selected ASEAN economies. International Business Research, 2(2), 156-166.

Mulualem Eshetu. (2006). Manufacturing Export: Performance and Determinants in Ethiopia,Birritu No. 103, National Bank of Ethiopia.

Nayaran K. . (2004). Reformulating Critical Values for the Bounds F-statistics Approach to Cointegration: An Application to the Tourism Demand Model for Fiji. Discussion Papers No: 02, Monash University, Victoria, Australia. .

Pesaran, B., Pesaran, M. H. . (2009). Time Series Econometrics Using Microfit 5.0. Oxford University Press, Oxford. . .

Pesaran, M., Shin, Y., \& Smith, R. . (2001). Bounds Testing Approaches to the Analysis of Level Relationships. Journal of Applied Econometrics, 16, 289-326. https://doi.org/10.1002/jae.616. . .

Rajni P. . (2013). Linkages between Export, Import and Capital Formation in India. International Research Journal of Social Sciences, 2(3), 16-19.

Redding, S. and A. J. Venables September. (2002). Explaining Cross-Country Export Performance: International Linkages and Internal Geography. Centre for Economic Performance London School of Economics and Political Science.

Rodrik D. . (2009). The real exchange rate and economic growth, in Brookings Papers on Economic Activity, Fall 2008, D.W. Elmendorf, N.G. Mankiw, \& L.H. Summers (Ed), 365-412. Washington, DC: Brookings Institution.

Romer P. M. . ( 1986). Increasing Returns and Long Run Growth. Journal of Political Economy, 94, 1002-1037.

Solow R. M . (1962). Technical Progress, Capital Formation, and Economic Growth. The American Economic Review, 52(2), 76-86.

Thangamani Bhavan . (2016). the Determinants of Export Performance: The Case of Sri Lanka; Eastern University, Sri Lank.

World Bank. (2012). World development indicators. CD-Rom, Washington, DC, the World Bank. Yi Lu, Q.L., \& Zhou, $Y$. (2013). Do exports respond to exchange rate changes? inference from China's exchange rate reform. University of International Business and .

World Bank. (2020). WWW.theglobaleconomy.com/https://www.focus-economics.com/ Ethiopia Economic Outlook. . 